\title{
A FELSŐOKTATÁS KÖLTSÉGVETÉSI FINANSZÍROZÁSÁNAK ÚJ IRÁNYAI*
}

\author{
Bordás Péter ${ }^{l}$
}

A felsőoktatás finanszírozásának számos modellje ismert a nemzetközi gyakorlatban, ha azon az elven indulunk el, hogy az állam vagy a hallgató finanszírozza tanulmányait. ${ }^{2}$ Elöbbi határozott elválasztás mellett a finanszírozási modellek változatosságát az egyházak, a különféle alapitványok, gazdasági szereplök által nyújtott támogatások, ösztöndij programok adják. Ezen belül nagy szórást mutat az, hogy az állam által nyújtott költségvetési támogatásoknak mekkora a súlya a rendszeren belül. A kontinentális Európát tekintve viszont meghatározó az állami szerepvállalás a finanszirozás tekintetében, különösen igaz ez a Kelet-közép európai országokra. Persze ez nem azt jelenti, hogy az államok jelentös forrásokat költenek a felsőoktatásra, inkább a finanszírozás egyöntetüségére utal, azaz arra, hogy az állami források hányada a meghatározó.

Magyarország esetében a 2010-es években indult egy reformhullám, mely az oktatás egész intézményrendszerét, finanszirozását, módszertanát érintette, az alapfokú oktatásról a felsőoktatásig. Az új irány mögött véleményem szerint az állami szerepvállalás felfogásának változása áll, mely egyébként a közszolgáltatások széles körét érintette, különösen a finanszirozás tekintetében. ${ }^{3}$ Az alapfokú oktatás ellátásáról való gondoskodást centralizálták, az önkormányzatok ez irányú feladatának megszüntetésével, s egy állami intézményfenntartó kialakitásával. Ezzel párhuzamosan a felsőoktatás kapcsán is számos strukturális reformnak lehettünk szemtanúi, így érdemes ezen új irányok mélyére nézni, különösen a finanszirozás szemszögéböl.

\section{Reformok a költségvetési hatékonyság érdekében}

A költségvetési finanszírozás átalakításának, hatékonyabbá tételének egyik elemenként értelmezhető az egyes intézményeket érintő integrációs változások. 2010-et követően számos koncepció született a reformok kivitelezésére, mely

\footnotetext{
* DOI 10.21867/KjK/2018.2.7.

${ }^{1}$ Dr. Bordás Péter PhD, tudományos munkatárs, MTA-DE Közszolgáltatási Kutatócsoport; egyetemi tanársegéd DE ÁJK

2 Bartha Ildikó (2016): Felsőoktatás-finanszírozás. In: Horváth M. Tamás - Bartha Ildikó (szerk.): Közszolgáltatások megszervezése és politikái. Merre tartanak? Budapest: Dialóg Campus, 2016, 720-746. old.

${ }^{3}$ Horváth M. Tamás - Bartha Ildikó (szerk.)(2016): Közszolgáltatások megszervezése és politikái. Merre tartanak? Budapest: Dialóg Campus.
} 
közül kiemelendő a Fokozatváltás a felsőoktatásban címü stratégia, melyet a felsőoktatásért felelős államtitkárság készített 2014-ben. E dokumentum alapvetően a teljesítményelvü felsőoktatás fejlesztésének irányvonalait határozta meg. ${ }^{4}$ A finanszírozás tekintetében már ekkor megfogalmazódott, hogy az intézményeknek egyre nagyobb mértékben kell támaszkodniuk saját bevételeikre (hallgatói költségtérítés), illetve a külső piaci forrásokra, s csökkenteni kell költségvetési függőségüket. Ugyanis ebben az időszakban a felsőoktatási intézmények finanszírozását kb. 50\%-ban a közvetlen állami támogatások, kb. $24 \%$-ban uniós pályázati források $(\mathrm{K}+\mathrm{F}), 22 \%$-ban az intézmény saját bevételei (tipikusan a hallgatói költségtérítés), a maradék 3-4 \%-ban pedig az egyéb harmadik féltól átvett támogatások (adományok, $\mathrm{K}+\mathrm{F}$ források) biztosították. ${ }^{5}$

Tehát már ekkor stratégiailag is megfogalmazásra került a költségvetési támogatások csökkentésének eszköze, mely a költségvetési adatokban is jól látható. $\mathrm{E}$ mellett feladatalapú költségvetési tervezési és gazdálkodási rendszer bevezetését is szorgalmazta, amely átlátható alapokra helyezi az intézményektől „megrendelt” közfeladatok ellátásának valós költségeit, azok finanszírozását. Az előzőekben említett állami szerepvállalás növekedése ekkortól érdekes formában figyelhető meg, a költségvetési források csökkentésre kerültek - mely alapján az állami szerepet háttérbe húzódását sejthetnénk -, ugyanakkor a felsőoktatás szabályozása (finanszírozási, feladat-ellátási, gazdálkodási stb.) erőteljesen állami kontroll alá került.

A finanszírozásban rögzítésre került több alapelv, így például az, hogy a finanszírozás alapja az elért teljesítmény, azaz nincsenek örökletes jogok. E körben azért megjegyezendő, hogy 2012-ben létrejött a Nemzeti Közszolgálati Egyetem, mely azóta is stratégiai szerepet tölt be a kormányzati politikában, így finanszírozása eltér a többi intézményétől, számos többletjogosítvánnyal rendelkezve. További alapelvkét került megfogalmazásra, hogy a költségvetési finanszírozás az állam által „megrendelt” feladatok elismert költségét fedezi. A gazdálkodásra vonatkozóan pedig deklarálták, hogy meg kell szabadítani a felsőoktatási intézményeket a saját erőből kigazdálkodhatatlan adósságoktól,

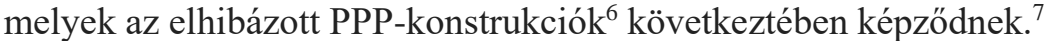

Mindezek mellett megállapítható, hogy a finanszírozás akkor és jelenlegi rendszere alapvetően hallgatói létszám alapú és semmilyen módon nem

\footnotetext{
4 Fokozatváltás a felsőoktatásban Elérhető: http://www.kormany.hu/download/d/90/30000/fels\%C5\%91oktat\%C3\%A1si\%20koncepci\%C3\% B3.pdf (letöltés dátuma: 2018. május 15.)

${ }^{5}$ Fokozatváltás a felsőoktatásban (2016): 80. old.

${ }^{6}$ Lásd erről részletesebben: Varga Judit (2015): 3P: Életképtelen jogalkotási vadhajtás vagy a közösségi igények kielégítésének müködőképes alternatívája? Közjavak, I. évf. 2015/1. szám, 1720. old.
}

${ }^{7}$ Fokozatváltás a felsőoktatásban (2016): 87. old. 
méltányolja a felsőoktatási teljesítményt, nem ösztönzi sem a hallgatókat, sem a felsőoktatási intézményeket a nagyobb teljesítményre, mely pont a fenti célkitüzést megvalósíthatná.

Az intézményi átalakítások megkezdése mellett (2013-2017 között 11 nagyobb intézményi átalakítás történt: beolvadás, kiválás) 2014 végétől, 2015 elejétől bevezetésre került a kancellári rendszer. A változás célja az átláthatóság elősegítése, a költségvetési szervek gazdálkodási hatékonyságának növelése volt, kiegészítve azzal, hogy így a kormányzati érdekek érvényesítése közvetlenül a felsőoktatási intézmény, mint költségvetési szerv szintjéig nyúlhat - ugyanis az volt az általános vélekedés, hogy az intézmények nem hatékonyan használják fel a költségvetési forrásokat, mely minőségromlással is jár. ${ }^{8}$ Ugyanis a koncellár felel a felsőoktatási intézmény gazdasági, pénzügyi, kontrolling, belső ellenőrzési, számviteli, munkaügyi, jogi, igazgatási, informatikai tevékenységéért, az intézmény vagyongazdálkodásáért, ideértve a műszaki, létesítményhasznosítási, üzemeltetési, logisztikai, szolgáltatási, beszerzési és közbeszerzési ügyeket is. ${ }^{9}$

Továbbá felállításra került a felügyelő testületként müködő konzisztórium, amelynek három tagját a miniszter nevezi ki, a kancellár mellett. A testület egyetértési joggal rendelkezik az intézményfejlesztési tervet, költségvetést, vagyongazdálkodást és a beszámolót illetően, továbbá a gazdálkodó szervezetek alapításával kapcsolatban, mely az állami szerepvállalás ilyes fajta növekedéseként magyarázható. ${ }^{10}$

Majd 2016-ban megszületett a Fokozatváltás a felsőoktatásban középtávú szakpolitikai stratégia 2016 címü cselekvési terv is, ${ }^{11}$ mely a 2016-2020 közötti feladatokat rögzítette. Ebben a finanszírozásra vonatkozó részek már mérsékeltebben kerültek megfogalmazásra, így például az, hogy a teljes oktatási rendszer finanszírozását nyilván nem lehet piaci alapokra helyezni, de az intézményeknek a szükséges források biztosítását tekintve több lábon kell állniuk a stabil müködés érdekében. A dokumentum továbbá kiemeli a kutatásfejlesztés forrásainak külső forrásból történő fedezésének igényét, azaz az intézményeknek meg kell próbálniuk pályázati forrásokból, külső partnerek

\footnotetext{
${ }^{8}$ Kováts Gergely - Temesi József (szerk.)(2018): A magyar felsőoktatás egy évtizede 2008-2017. NFKK Kötetek 2. Budapesti Corvinus Egyetem, 70 old.

${ }^{9}$ Nemzeti felsőoktatási törvény 13/A. §.

${ }^{10}$ Lásd ehhez részletesebben: Kováts Gergely (szerk.): A kancellári rendszer bevezetése a magyar felsőoktatásban. Budapesti Corvinus Egyetem, 2016.

${ }^{11}$ http://www.kormany.hu/download/b/fa/11000/EMMI\%20fokozatv\%C3\%A1lt\%C3\%A1s\%20fe 1s\%C5\%91oktat\%C3\%A1s\%20cselekv\%C3\%A9si\%20terv\%20Sajt\%C3\%B3\%20\%C3\%A9s\%2 0Kommunik\%C3\%A1ci\%C3\%B3s\%20F\%C5\%910szt\%C3\%A1ly\%2020170627.pdf (letöltés dátuma: 2018. május 15.)
} 
bevonásával előteremteniük az erre fordítandó összegeket ${ }^{12}$, megjegyezendő, hogy hazánkban különösen alacsony az ilyen forrásbevonási képesség.

A finanszírozásra vonatkozóan számos célkitüzés és cselekvési eszköz rögzítésre került, melyek átültetése bár folyamatban van, de gyorsabb és hatékonyabb megoldást igényelnének. Összességében az látható, hogy az egyetemek pénzügyi autonómiája csökkent, a csökkenő források és a kormányzati befolyás növekedése által. ${ }^{13}$

\section{A költségvetési finanszírozás nagyságrendi változása}

A felsőoktatási intézmények bevételi struktúrájában, mint már említésre került az állami költségvetési források mindig is meghatározóak voltak, jellemzően a bevételi források több mint felét teszik ki.

2010-et követően az intézményi átalakításokkal és az államilag támogatott képzési formák hallgatói létszámának csökkentésével egyidejüleg fokozatosan csökkent a felsőoktatás GDP arányos támogatása. Az EUA (European University Association) adatai alapján 2008 és 2016 között $25 \%$-al csökkent az egyetemre felvett hallgatók száma, melyet kisebb-nagyobb mértékben a finanszírozás is lekövetett. ${ }^{14}$

1. táblázat

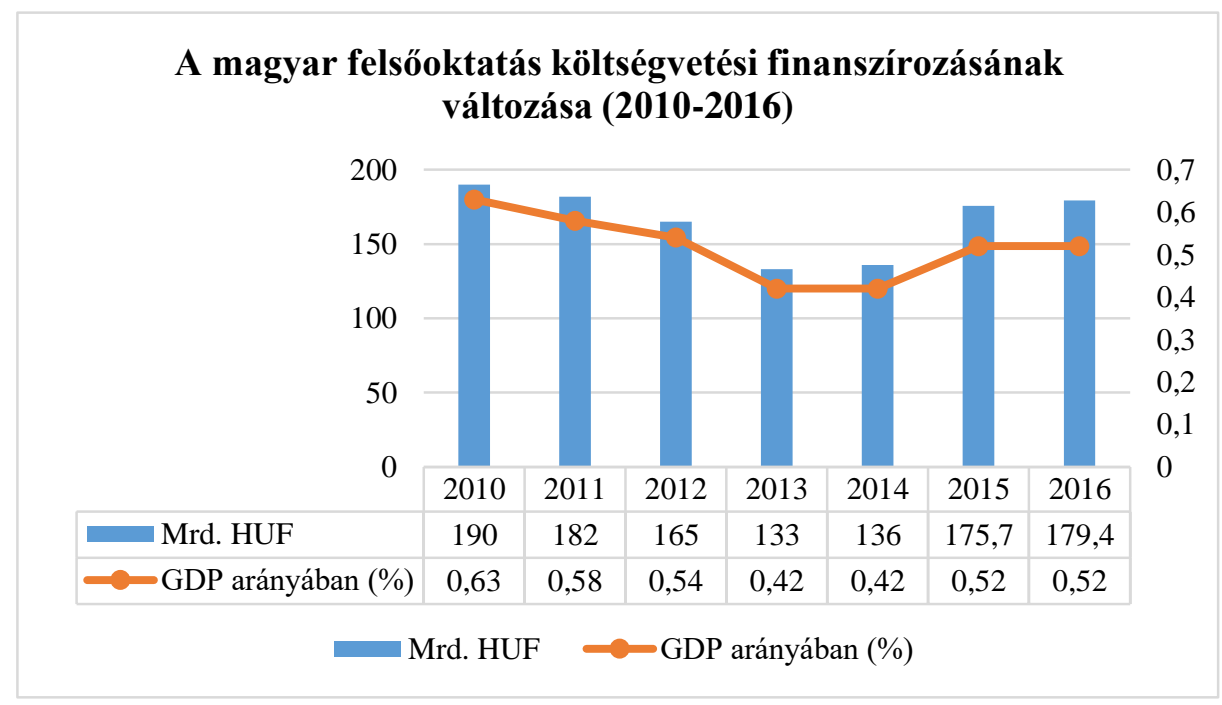

Forrás: a szerző saját szerkesztése az EUA adatai alapján

\footnotetext{
${ }^{12}$ Fokozatváltás a felsőoktatásban középtávú szakpolitikai stratégia 2016 című cselekvési terv, 48.

${ }^{13}$ Pruvot, Enora Bennetot - Estermann, Thomas (2017): University Autonomy in Europe III The Scorecard 2017, Brussels: EUA, 23.

${ }^{14}$ Pruvot - Estermann (2017): i.m.
} 
Az 1. számú táblázat 2010 és 2016 között mutatja a jelenleg elérhető költségvetési zárszámadások alapján a felsőoktatásra fordított összegek nagyságát, az oszlopdiagram forintban, míg a vonaldiagram a GDP arányában meghatározva. Mindkét adatsor elemezve megállapítható, hogy 2010-től 2013ig folyamatosan csökkent a támogatás mértéke, majd 2014-től ismét emelkedett, de a korábbi szintet még így sem érte el.

Érdemes néhány, az adatokat árnyaló, pontosító megjegyzést is tenni. Jól látható, hogy az államháztartás újraelosztási funkciója keretében a felsőoktatásra még 2010-ben is csupán csak 0,63\%-ot költött az állam, s a korábban deklarált kívánatos 1 \%-os szintre való emelkedést, a 2013-14-es mélypont után még 2016-ban sem érte el, sőt a korábbi 2010-es szintet sem. Persze ez csak az költségvetési források szintje, s ha valamennyi forrást összeadunk akkor valamelyest szebb képet kapunk. Ugyanis 2016-ban a felsőoktatás teljes kiadása a GDP 1,38 \%-át tette ki, azaz az állami forrás mellett jelentős a magánfinanszírozás is járult hozzá. Ez pedig a korábban ismertetett stratégiákkal vág egybe, miszerint a magánfinanszírozás erősítésére kell építkezniük az intézményeknek.

Kevésbé pozitív képet kapunk, ha a 2008-as évet bázisnak véve vizsgáljuk a finanszírozás alakulását, mert akkor a 2016-os évre 29,08\%-al csökkent összességében a felsőoktatás költségvetési finanszírozása. A 2015-2016 között tapasztalható - s az ábrán látható - támogatás növekedése nem feltétlenül azt jelenti, hogy az intézmények fejlesztésére, az oktatás színvonalának növelésére kaptak volna plusz forrást, hiszen annak jelentős eleme az oktatói bérek emelésével járó többletkiadások kompenzálása. ${ }^{15}$

Továbbá fontos megjegyezni, hogy Magyarországon alapvetően az állam kínálati finanszírozása figyelhető meg, azaz a felsőoktatási intézményeket támogatja meghatározott hallgatói helyek kínálata érdekében, mely nagyban képes befolyásolni a pályaválasztást, $\mathrm{s}$ ez által a hallgatói teljesítményt is (sajnos negatív irányba - ha csak azért megy valaki az adott szakra mert ott biztosít állami ösztöndíjat az állam, miközben az adott pályához nincs érzéke a hallgatónak).

E körben, végezetül az is megjegyezendö, hogy a finanszírozásban nehezen kimutatható, de egyre nagyobb szerepe lehet a tárgyalásos alapon működő rendszernek, ahol az intézmény vezetése közvetlen tárgyalásokat folytat a kormányzattal a források megszerzése érdekében. Különösen a 2012/13-as jelentős forráscsökkentést követen tapasztalhatjuk ennek a gyakorlati jelentőségét.

Érdekes utolsóként az intézmények pénzügyi autonómiájának kérdését is szemügyre venni. Az EUA legfrissebb 2017-es felmérése nagyon változatos

15 395/2015. (XII. 12.) Korm. rendelet alapján három lépcsőben, 15+5+5\%-os emelkedést hajtottak vége az oktatói bérekben. 
képet mutat Európa egyes országai között, melyet az 1. számú ábra szemléltet. ${ }^{16} \mathrm{~A}$ szervezet pontozási rendszer alapján sorolta négy klaszterbe az egyes országok felsőoktatási intézményrendszerét.

1. ábra

\section{A felsőoktatás pénzügyi autonómiájának alakulása egyes európai} országokban, 2017
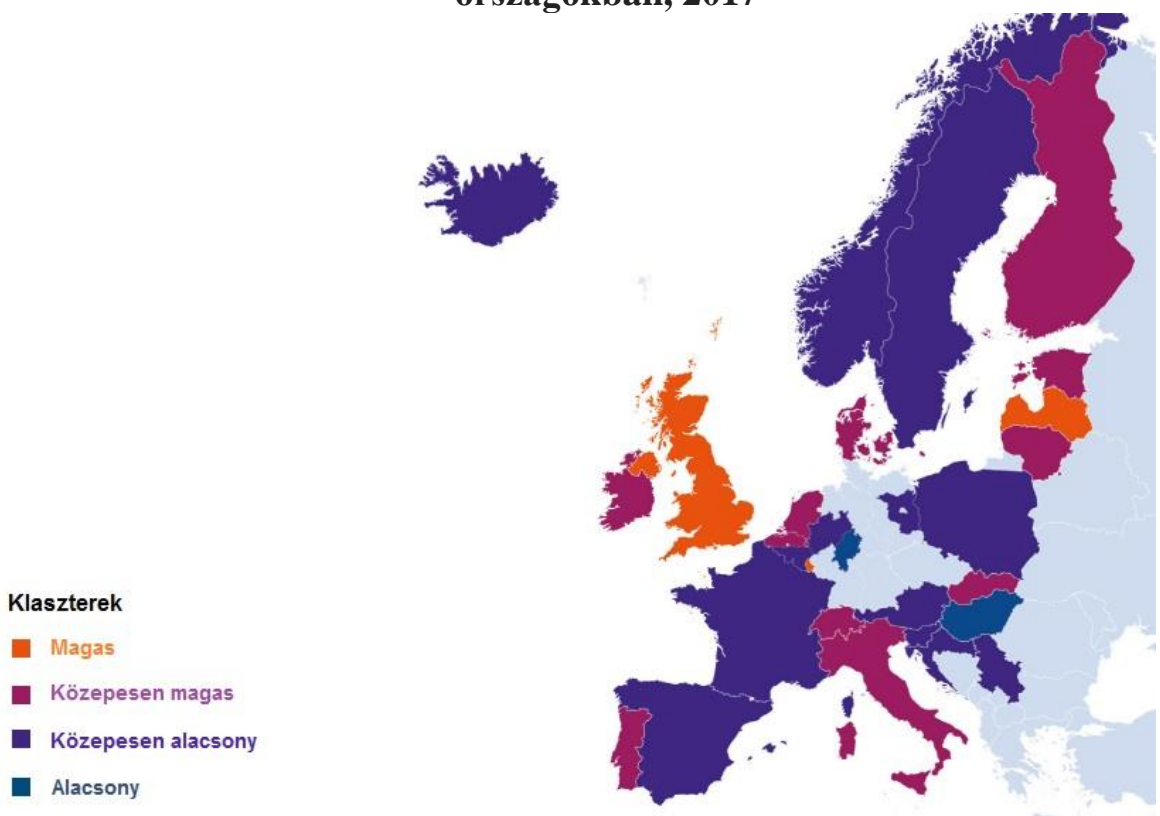

Forrás: a szerző által az EUA ábrájának magyarosított változata

A pontozásos rendszer alapján a vizsgált 29 ország/tartomány ${ }^{17}$ közül Luxemburg intézményrendszere került az élre $91 \%$-al, mint amelyik magas pénzügyi autonómiával rendelkezik. Míg a klaszter másik végén az alacsony pénzügyi autonómiával rendelkező osztályban található Magyarország $39 \%$-al, csupán a német Hesse tartományt megelózve (35\%). Tehát a fentebb felsorolt hazai intézkedések hatását jól kivehetjük a pénzügyi autonómiában is. Persze önmagában az nem jelent semmit, hogy magas vagy alacsony kategóriába tartozik egy ország, mindez a hatékonyság, a teljesítmény és az oktatás színvonala tükrében értékelhető.

\footnotetext{
${ }^{16}$ Pruvot - Estermann (2017): i.m. 44-45. old.

${ }^{17}$ Németország esetében csupán három tartomány intézményrendszerét vizsgálta a felmérés.
} 


\section{$* * *$}

Összességében megállapítható, hogy egy többirányú folyamatról beszélhetünk a felsőoktatás finanszírozásának változásában. Számos, az egyetemi pénzügyi autonómiát csökkentő intézkedést került bevezetésre. Az állami szerepek növekedése együtt jár a finanszírozás megvágásával, tehát csökkent a finanszírozás, nőtt az intézményekre gyakorolt állami befolyás. 2010-et követően egy „V” alakú görbével írható le a felsőoktatás költségvetési finanszírozása, azaz a csökkenést követően ismét emelkedett az erre fordított összeg, de nominálisan továbbra sem érte el a korábbi szintet. Ezek tükrében érdekes lesz figyelni a 2017-es költségvetési beszámoló adatait, hogy merre mozdul el a rendszer. A költségvetési tervezetekből ugyanakkor az látszik, hogy folytatódni fog a növekvő ütem, kérdés az, hogy milyen mértékben?

\section{Források jegyzéke:}

- Bartha Ildikó (2016): Felsőoktatás-finanszírozás. In: Horváth M. Tamás - Bartha Ildikó (szerk.): Közszolgáltatások megszervezése és politikái. Merre tartanak? Budapest: Dialóg Campus.

- Horváth M. Tamás - Bartha Ildikó (2016) (szerk.): Közszolgáltatások megszervezése és politikái. Merre tartanak? Budapest: Dialóg Campus.

- Kováts Gergely (2016) (szerk.): A kancellári rendszer bevezetése a magyar felsőoktatásban. NFKK Kötetek 1. Budapesti Corvinus Egyetem.

- Polónyi István (2018): A hazai felsőoktatás elmúlt 10 évének néhány gazdasági jellemzője. In: Kováts Gergely - Temesi József (szerk.) (2018): A magyar felsőoktatás egy évtizede 2008-2017. NFKK Kötetek 2. Budapesti Corvinus Egyetem, 79-97. old.

- Pruvot, Enora Bennetot - Estermann, Thomas (2017): University Autonomy in Europe III The Scorecard 2017, Brussels: EUA, 23.

- Varga Judit (2015): 3P: Életképtelen jogalkotási vadhajtás vagy a közösségi igények kielégítésének működőképes alternatívája? Közjavak, I. évf. 2015/1. szám, 17-20.

- Varga Judit (2017): Állami szerepek a felsőoktatásban Közpénzfelhasználás hazai defektusai a magánszektor infrastruktúrafejlesztésbe vonása esetén. JURA 23:(1), 403-414.

- 2011. évi CCIV. törvény a nemzeti felsőoktatásról

- 395/2015. (XII. 12.) Korm. rendelet a közalkalmazottak jogállásáról szóló 1992. évi XXXIII. törvény felsőoktatásban való végrehajtásáról és a felsőoktatási intézményben való foglalkoztatás egyes kérdéseiről

- Fokozatváltás a felsőoktatásban középtávú szakpolitikai stratégia 2016.

- Fokozatváltás a felsőoktatásban 2014. 